\title{
Fibroadenom İçinde Saptanan Yerleşmiş Duktal Karsinoma in Situ
}

\author{
Ductal Carcinoma in Situ Located into Fibroadenom: Case Report
}

\author{
Turan ACAR ${ }^{1}$, Ercüment TARCAN ${ }^{1}$, Yunus Emre DANIŞ ${ }^{1}$, Yelda DERE ${ }^{2}$, Deniz YILDIZ ${ }^{1}$, \\ Emir ÇAPKINOĞLU ${ }^{1}$, Murat Kemal ATAHAN ${ }^{1}$, Nihan COŞGUN ${ }^{1}$ \\ ${ }^{1}$ İzmir Katip Çelebi Üniversitesi Atatürk Eğitim Araşttrma Hastanesi 1. Genel Cerrahi Kliniği, İZMïR \\ ${ }^{2}$ İzmir Katip Çelebi Üniversitesi Atatürk Ĕgitim Araştırma Hastanesi Patoloji Kliniği, İZMİR
}

\begin{abstract}
ÖZET
Fibroadenom sitolojik atipi olmaksızın düşük sellülarite gösteren fibröz stromadan oluşan tümörlere verilen isimdir. Bu tümörler genellikle genç kadınlarda görülürler. Kolayca hareket ettirilebilen, mobil kitlelerdir, makroskopik görünümleri genellikle karakteristik ve tanı koydurucudur. Duktal karsinoma in situ (DKİS) ise, meme duktusuna sınırlı malign epitelyal hücre proliferasyonu ile karakterize, patolojik ve biyolojik davranış özellikleri ile heterojen bir lezyon grubudur.

Polikliniğimize sağ meme saat 12 hizasında ele gelen kitle şikâyeti ile başvuran 28 yaşında bayan hastada çekilen ultrasonografide $2,5 \times 2 \mathrm{~cm}$ boyutunda düzgün sınırlı fibroadenom görüntüsü ile uyumlu kitle hastanın isteği ile çıkarıldı. Patoloji sonucu fibroadenom içine yerleşmiş duktal karsinoma in situ olarak yorumlandı. Hastanın postoperatif dönemde çekilen ultrasonografisinde sol alt kadranda da fibroadenoma rastlandi. Taramalarında metastatazı düşündürecek patolojik bulgu yok idi.

Son yapılan çalışmalarda, hastanın yaşından veya diğer sorunlarından bağımsız olarak tüm fibroadenomların çıkartılması önerilmiştir. Fibroadenomların "iyi huylu" olduğundan emin olsak bile belirli peridyodlarla "şüpheli" herhangi bir yeni bulgu taşıyı taşımadığına hastanın yaşına uygun tarama yöntemleriyle bakmak zorundayı.
\end{abstract}

Anahtar Kelimeler: Fibroadenom, duktal karsinoma, in situ
ABSTRACT

Fibroadenoma is a gruop of tumor with low cellularitied fibrous stroma without cytologic atypia. Fibroadenomas generally seen on young women. They are movable and macroscopic appearance is characteristical and diagnostic. On the other hand ductal carcinoma in situ(DCIS) is a heterogenous group of lesion on pathological and biologic performance which is limited into mammary ductus and characterized by malign epithelial cell proliferation.

28 years old woman patient with presenting a palpable mass on right mammary 12 o'clock side complaint in polyclinic was applied ultrasonography and diagnosed a $2,5 \times 2 \mathrm{~cm}$ sized wellcircumscribed lesion which is compatible with fibroadenoma. This mass was removed surgically because of patient request. Removed material was reported as ductal carcinoma in situ located into fibroadenoma. Another fibroadenoma on lower inner quadrant was detected by ultrasonography on postoperative period. Any pathological finding compatible with metastasis was not found on routine tests.

According to recently articles it is suggested to excise all fibroadenomas separately patient age and other indicators. Even if we are sure about fibroadenomas are "benign", we should detect of patients having any new "suspicious" symptom in regular periods by diagnostic tests suitable for patient age.

Keywords: Fibroadenom, ductal carcinoma, in situ

* Bu makale 12. Ulusal Meme Hastalıkları Kongresinde poster olarak yayınlamıştır.

KÜ T1p Fak Derg 2014; 16(2): 40-43

Geliş Tarihi / Received: 06.12.2013

Kabul Tarihi / Accepted: 16.01.2014
Yazışma Adresi / Correspondence: Turan ACAR

172 Sok. No: 3/1 Basın Sitesi, İMIR

E-posta: drturanacar1982@gmail.com Tel: 05072153104 


\section{GíRiș}

Fibroadenom sitolojik atipi olmaksızın düşük sellülarite gösteren fibröz stromadan oluşan tümörlere verilen isimdir. Kolayca hareket ettirilebilen, mobil kitlelerdir, makroskopik görünümleri genellikle karakteristik ve tanı koydurucudur (1). Duktal karsinoma in situ (DKİS) ise, meme duktusuna sınırlı malign epitelyal hücre proliferasyonu ile karakterize, patolojik ve biyolojik davranış özellikleri ile heterojen bir lezyon grubudur. Fibroadenom içinde karsinom gelişmesi literatürlerde nadir görülen bir durumdur $(2,3)$. Genellikle fibroadenom ön tanısıyla çıkartılan kitlede tesadüfi olarak görülürler.

\section{OLGU}

Polikliniğimize sağ memede ele gelen kitle şikâyeti ile başvuran 28 yaşında bayan hastada yapılan fizik muayenede; sağ meme üst dış kadranda mobil iyi sınırlı yaklaşık 3 cm'lik kitle palpe edildi. Bunun üzerine çekilen ultrasonografide $2,5 \times 2 \mathrm{~cm}$ boyutunda düzgün sınırlı fibroadenom görüntüsü ile uyumlu kitle tespit edildi. Ailede meme kanseri hikâyesi olmayan hastanın isteği, radyolojik bulgular ve yaşı göz önüne alınarak iyi huylu olduğu düşünülen kitle çıkarıldı. Patolojik inceleme sonrasi $2,5 \times 2 \mathrm{~cm}$ boyutlarında fibroadenom içine yerleşmiş duktal karsinoma in situ olarak saptand 1 (Resim 1).

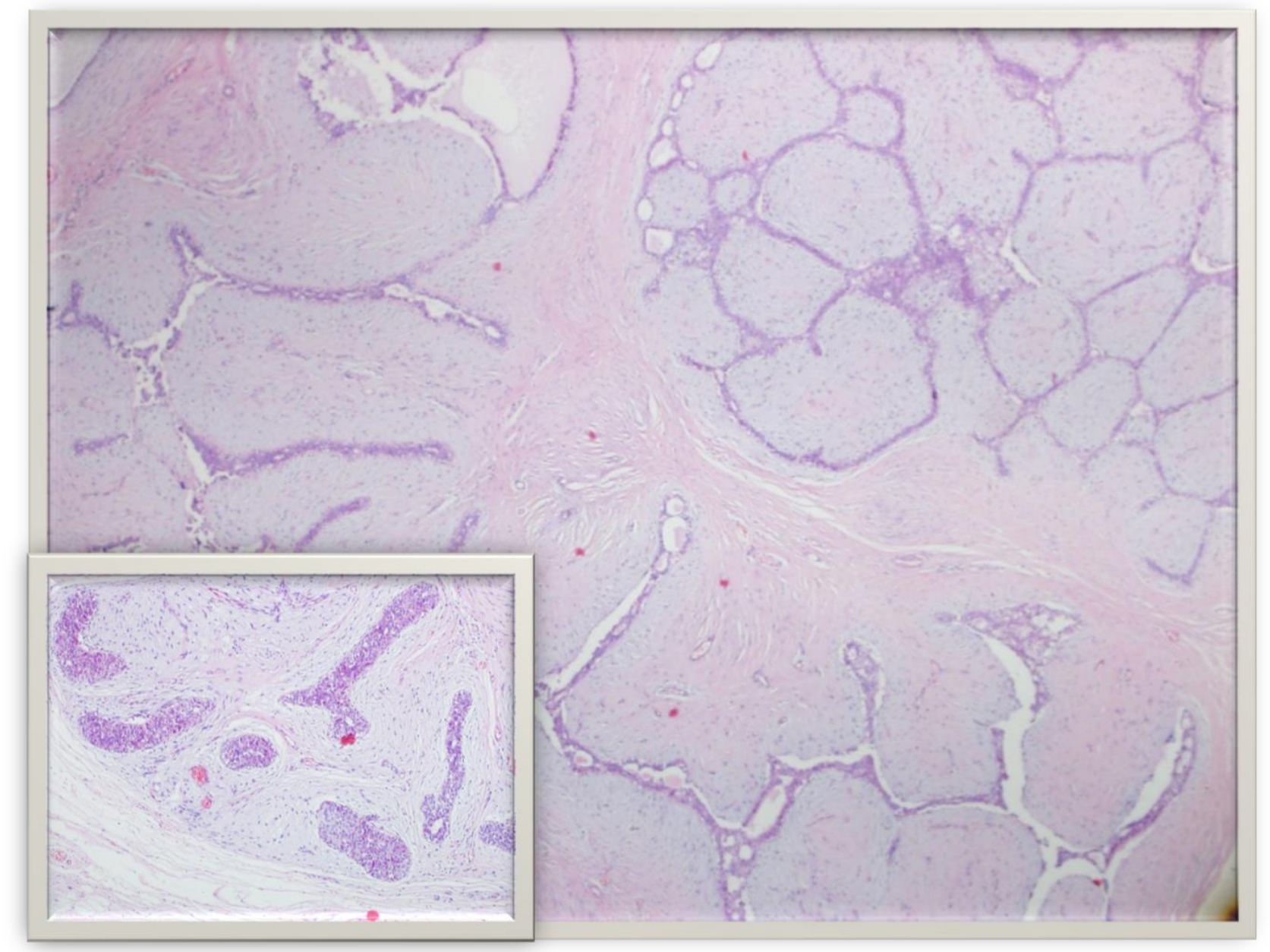

Resim 1: Fibroadenom İçindeki Duktal Karsinoma in situ Alanları, HE 
ER +2 idi. Hastanın postoperatif dönemde çekilen USG de sol alt kadranda da fibroadenoma rastlandi. Taramalarında metastatazı düşündürecek patolojik bulgu yok idi. Takiplerinde herhangi bir lokal nüks veya metastatik odağa rastlanmadı.

\section{TARTIŞMA}

Fibroadenom genellikle karsinom oluşumu için risk faktörü olarak kabul edilmez. Fibroadenom içinde karsinom oluşumu nadirdir (2,3). BuzanowskiKonarky ve ark. yaptığı çalışmada 4000 fibroadenom tanılı hastadan sadece 5 'inde karsinom odağına rastlanmıştır (4). Ortalama 42,4- 44 yaşları arasında görülür. Normal de fibroadenomlara genellikle daha genç yaş grubunda rastlanıldığından, ileri yaşta fibroadenom düşünülen hastalarda karsinom odağından şüphelenilmelidir.

Birçok hastada aynı veya karşı tarafta senkron kitleler bulunabilir fakat ele gelen lenf nodlarına rastlanmaz $(4,5)$. Bizim hastamızda da yapılan taramalar sonucu karşı memede senkron kitle bulunmasına rağmen, her iki aksillada da lenf nodu yok idi.

Diaz ve ark., fibroadenom içinde görülen karsinomların \% 95 ini karsinoma in situların oluşturduğunu, bunlardan da LCİS ve DCİS'nun eşit oranda görülebileceğini belirtmiştir (2). Fakat Mc Divitt ve ark. yaptığ 1 bir çalışmada ise; \%50 oranında LCİS, \%22 DCİS, \%17 invaziv duktal karsinoma, \%11 oranında ise invaziv lobüler karsinoma rastlanmıştır (6).

Fibroadenom içinde kötü huylu bir odağı belirlemek için güvenilir bir klinik kriter yoktur. En sık görülen belirti, boyutları $0,5 \mathrm{~cm}$ ile $10 \mathrm{~cm}$ arasında değişen, ele gelen mobil kitledir. Tipik bir fibroadenoma göre anormal mammagrofik bulgu verebilirler. Fibroadenom içinde mikrokalsifikasyon odakları görülebilir (7). Renkli doopler USG de kitlenin anjiogenezisi artmış olarak görülür. $\mathrm{Bu}$ hastalarda belirli odaklarda karsinom olduğundan ince iğne aspirasyon biyopsisi bizi yanıltabilir.
Tedaviyi belirlemede BRCA1-2, gibi genetik belirteçlerin kullanılması yararlı olabilir. Lokal eksizyon ve radyoterapi, mastektomi ve hormonoterapiye kıyasla DCİS tedavisinde en popüler yaklaşımdır. $\mathrm{Bu}$ vakada lezyonun tümü fibroadenom içinde sınırlı ve hasta genç yaşta olduğu için lokal eksizyon ve sonrasında radyoterapi uygulanmıştır. Diaz'ın yapmış olduğu bir çalışmada 8 yıllık takipte fibroadenom içi DCİS tespit edilen olgularda nüks oranı \%3,8 olarak bildirilmiştir (2). Bu tip hastalarda ileri tedaviye karar verilirken hastanın görüşünü almak gerekmektedir. Hastada var olan diğer fibroadenomlara nasıl yaklaşılması gerektiği ve bu diğer fibroadenomlarda DCİS görülme oranı ise halen tartışma konusudur.

Son yapılan çalışmalarda, hastanın yaşından veya diğer sorunlarından bağımsız olarak tüm fibroadenomların çıkartılması önerilmiştir. Fibroadenomların "iyi huylu" olduğundan emin olsak bile belirli periyodlarla “şüpheli” herhangi bir yeni bulgu taşıyıp taşımadığına hastanın yaşına uygun tarama yöntemleriyle bakmak zorundayız. Bu hastaların tanı ve tedavilerinin ise diğer DCİS hastaları ile aynı olması gerektiği kanaatindeyiz.

\section{KAYNAKLAR}

1. Sakorafas GH, Farley DR, Peros G. Recent advances and current controversies in the management of DCIS of the breast. Cancer Treat Rev 2008. doi: 10.1016/j. ctrv. 2008.03.001 (PubMed PMID: 18490111).

2. Diaz NM, Palmer JO, Mc Divitt RW. Carcinoma arising with in fibroadenomas of the breast: a clinico pathologic study of 105 patients. Am J Clin Pathol. 1991; 95: 614-22 (PubMed PMID: 1850948).

3. Ozzello L, Gump FE. The management of patient swith carcinomas in fibroadenoma tous tumors of the breast. Surg Gynecol Obstet. 1985; 160: 99-104. (PubMed PMID: 2982218). 
4. Buzanowsky- Konarky K, Harrison EG, Payne WS. Lobular carcinoma arising in fibroadenoma of the breast. Cancer. 1975; 35: 450-56. (PubMed PMID: 1111920).

5. Pick PW, Iossifides IA. Occurrence of breast carcinoma within a fibroadenoma: a review. Arch Pathol Lab Med. 1984; 108: 590-96 (PubMed PMID: 6329129).
6. Mc Divitt RW, Stewart FD, Farrow JH. Breast carcinoma arising in solitary fibroadenomas. Surg Gynecol Obstet. 1976; 125: 572-76 (PubMed PMID: 6035784).

7. Fondo EY, Rosen PP, Fracchia AA, Urban JA. The problem of carcinoma developing in a fibroadenoma. Cancer. 1979; 43: 563-67. (PubMed PMID: 217522). 